\title{
Refugee Without Refuge: Wasim, Phillip Adams, and a Nation Divided
}

\author{
Anne Pedersen and Farida Fozdar \\ Murdoch University, Australia
}

\begin{abstract}
This study follows on from previous work (Pedersen et al., 2008) that examined the situation of the stateless asylum seeker, Wasim. In the present study, a blog discussion stemming from an editorial about Wasim (Adams, 2008) was analysed. Participants were identified as 'Do-Gooders' and 'Do-Badders'; categories that indicate their orientation to asylum seeker debates (labels originated from the blog itself). We identified several features of the blog discussion. While similar themes and discursive devices were used by the two groups, they were used very differently. The Do-Gooders were more likely to offer accurate information about asylum seekers or Wasim and to show humanitarian concerns for Wasim and others like him. The Do-Badders were more likely to display emotion, show the 'Phillip Adams Effect' (addressing the author of the editorial, Phillip Adams, in their submissions) and name-call. However, there was no significant difference with respect to whether participants addressed Wasim's situation specifically rather than focusing on the general issue of asylum seekers. The blog demonstrates, in microcosm, the divided orientation of Australians regarding asylum seekers.
\end{abstract}

Keywords: asylum seeker, anti-prejudice, anti-racism, refugee activism, refugee advocacy

The present study develops previous research that examined the situation of a stateless asylum seeker Wasim who has been in Australia for over 10 years without resolution of his situation (Pedersen, Kenny, Briskman, \& Hoffman, 2008). Before we outline this particular case, a little background about asylum seeker issues in Australia is appropriate. Australia's migration policy includes a quota for people who need humanitarian assistance. These places are usually filled offshore with the help of the United Nations High Commissioner for Refugees (UNHCR); however, some people arrive in Australia by other means and apply for refugee status once here they are known as asylum seekers. For the last decade, those who arrive without any visa (i.e., usually those who come on unauthorised boats), were held in detention centres until a determination on their case was made. Until 2007, asylum seekers would only be granted temporary protection visas, even if found to be genuine refugees. These asylum seekers, along with those on other visa categories such as temporary humanitarian visas and removal pending bridging visas, were provided limited rights for a limited time (Crock \& Saul, 2002; Holinsworth, 2006; Mares, 2002).
Asylum seekers have regularly been used for political ends and the issue was credited for the conservative Coalition government's 2001 electoral win and for the popular appeal of Prime Minister John Howard (Gale, 2004; Jupp, 2002). Discursive analyses of the media and politicians' speeches identify a climate of hostility that surrounds asylum seekers and refugees. They are routinely represented as illegal, illegitimate and threatening and are constructed not simply as a problem, but as deviant in a variety of ways. To depict asylum seekers as ungrateful, unworthy, aggressive, demanding, economically draining, polluting and different, the language of war and of criminality is recruited (see Gale, 2004; Mares, 2002; Manne \& Corlett, 2004; Pickering, 2001; Saxton, 2003). The use of dehumanising terms such as 'human cargo' and 'illegals', and accusations of deviance such as 'throwing children overboard' in order to lure rescue ships, and being queue-jumpers, reinforce the difference between 'them' and 'us'. It is in this context that the discussion of Wasim's case occurred.

Wasim is from Indian-controlled Kashmir; his father was murdered by the Indian forces and his mother died shortly afterward. Wasim was arrested and tortured for 10 days and then taken to what was likely to be his 
execution. He escaped and after a convoluted journey made it to Australia and sought asylum (Pedersen et al., 2008). His visa application was rejected. The Refugee Review Tribunal - consisting of one person - accepted most of Wasim's claims; however, he considered Wasim's experience a 'single instance' and was not satisfied that it would occur again if Wasim was returned to Kashmir. It is appropriate here to consider the definition of a refugee. The United Nations' Universal Declaration of Human Rights, December 10, 1948, adopted and proclaimed by General Assembly resolution 217 A (III) Article 14, states that 'Everyone has the right to seek and to enjoy in other countries asylum from persecution'. The 1951 United Nations Convention relating to the status of refugees defines a refugee as

a person who: owing to a well-founded fear of being persecuted for reasons of race, religion, nationality, membership of a particular social group, or political opinion, is outside the country of their nationality, and is unable to or, owing to such fear, is unwilling to avail him/herself of the protection of that country.

As it happened, however, Wasim could not be returned to Kashmir because India would not recognise him as an Indian national. Thus, for all intents and purposes, he is 'stateless' (for more information about statelessness worldwide, see Couldrey \& Herson, 2009). Wasim spent 5 years in detention under Australia's policy of detaining asylum seekers (see Jupp, 2002; Mares 2002) and 4 years in the Western Australian community unable to work, receive social security or health care. He was supported entirely by his wife (an Australian citizen), a charitable organisation and friends. He was then granted a removal pending bridging visa (RPBV), which remains current. This means that although he can work and access health care/social security, he lives in fear of being returned to his homeland. From the day he was given an RPBV, he has been working 6 days a week, 10 hours a day, in his wife's security door business. The business has doubled in the 18 months he has been in charge, and now has six Australian employees.

One year after being granted a RPBV, and with no movement from the Immigration Department (despite the change in government one year earlier), Phillip Adams - a left-wing social commentator for the national newspaper The Weekend Australian - wrote an article called 'Refugees without Refuge' outlining Wasim's situation and calling for a compassionate resolution to the case based on Australia's ratification of the UN Convention relating to Stateless Persons (Adams, 2008). Immediately, on-line bloggers at The Australian site entered into a discussion, with some supporting and some opposing Adams' position. By the time approximately 40 bloggers had participated in the discussion, the first author, who is also Wasim's primary advocate, decided to analyse the responses with the help of the second author. The first author had already contributed to the blog; however, this was before any decision was made to analyse the data.

Both authors, one a community/social psychologist, the other a sociologist, recognise the impossibility of a value-free social science (see Liamputtong \& Ezzy, 2005; May 1997; Pedersen et al., 2008), and at the outset note that Australia is signatory to The Convention Relating to the Status of Stateless Persons (1954) and The Convention on the Reduction of Statelessness (1961). These conventions require Australia to protect and assist stateless people in whatever ways possible, including granting nationality. This is the position that the authors hold.

Unlike much psychological research, we use naturally occurring data. We recognise that contributors to a blog such as this are not a representative sample of Australians, but are likely to include those who feel most strongly at either end of the asylum seeker debate spectrum. We see this as an advantage. As noted by Billig (1987), when one makes an argument, it is directed toward a competing opinion. So it would be useful for anti-prejudice strategists to know the 'rival' position. This is especially the case given that people with strong opinions are likely to publicly shape the context of prejudice. Furthermore, people with highly prejudiced views are more likely to think that their views are shared (e.g., Hartley \& Pedersen, 2007) and this may give them the incentive to speak more freely with respect to their hostile views. Thus, naturally occurring data have two major benefits. The first is to obtain information without any contamination from specifically asked questions. The second is to compare extreme views of a topic such as this.

\section{Method \\ Participants}

A total of 55 participants submitted an opinion to The Australian's blog. A total of 51\% identified as male, 29\% identified as female and $20 \%$ we were unable to judge. Some participants engaged in the process more than once: three participants' names were repeated (two who supported Wasim and one who did not). We do not use the names given on the blog within this analysis as some bloggers chose to use their real names. While the information is public, we felt it more ethical to give the participants privacy. With respect to the characterising of these two groups' broad opinions, we took our lead from the participants themselves. Participant No. 33 called people with views different to himself 'clueless Do-Gooders' and Participant No. 44 responded by calling people like him 'Do-Badders'. The other bloggers did not enter into this particular exchange of words. We acknowledge that both terms, Do-Gooder and DoBadder, can be perceived and/or used pejoratively. For the Do-Badders, there is an implication that they are bad people. Conversely, the term Do-Gooders is often prefaced by an insulting adjective (for example, 'clueless' 
as occurred in the present study) and is associated with 'politically correct' and naïve understandings of the world. However, in order to categorise participants using their own words, while also reflecting the binary between those that supported the legitimacy of Wasim and/or asylum seekers and those who opposed such legitimacy, we labeled the two groups 'Do-Gooders' (minus the pejorative adjective 'clueless') and 'DoBadders'. In short, we simply followed participants' labels of people who either supported or opposed Wasim. We are not making a judgment on participants' 'goodness' or 'badness'.

\section{Method of Analysis}

We used two forms of analysis: qualitative and quantitative. As noted by Cohen (2007), all methods have their strengths and weaknesses; it is best to use a 'full toolkit of techniques' (p. 223). First, a thematic analysis (see Braun \& Clarke, 2006) was conducted on the corpus of qualitative data. Themes, which are simply particular characteristics or patterns found in the data, were generated inductively, using a form of 'open coding' suggested by Glaser and Strauss (1980). Careful reading of the blog entries, focusing in this instance on the content of what was said produced the set of themes identified. Key themes were those characteristics or patterns that were found in a majority of the postings. Subthemes within those major categories were also found. With regard to what distinguishes a theme from a subtheme, themes are overarching categories while subthemes are specific but different issues relating to the overarching category. At the outset a few points must be noted. We acknowledge that some of the themes identified overlap, leaving nonmutually exclusive categories. This does not affect the validity of the analysis because each category is analysed in its own terms. Furthermore, although in laboratory experiments these sorts of categories can be separated, in the 'real world' categories do overlap with one another.

After a first reading of the data, six major themes or characteristics were identified (the demonstration of emotions, the Phillip Adams effect, name-calling, the provision of information, humanitarianism, the mentioning of Wasim). Before analysing these major themes, we were interested in two other issues: first, whether participants were Do-Gooders or Do-Badders as this comparison forms the basis of much of the present article. We were also interested in how much explicit prejudice was espoused. On first reading, this did not seem to be a major theme but one worth briefly pursuing.

To assess whether there was agreement between the two researchers regarding coding, we conducted interrater reliability according to the guidelines of Landis and Koch (1977) on the measurement of categorical data (kappa analyses). Rating was performed by each author. The unit of analysis was each blog entry taken as a whole. We did not 'fracture' the data as is recommended by some authors (for example, Glaser \& Strauss, 1980). We believed it more appropriate to treat the entries holistically as units. Most entries were only a few sentences long (if that) thus making coding by entry relatively simple. This allowed the same posting to be coded for different themes. Interrater reliability was high. Of the eight variables, as per Landis and Koch's guidelines, two had a perfect match (1.00), four an almost perfect match (0.81$1.00)$, one a substantial match $(0.61-0.80)$, and one a fair match $(0.21-0.40)$. A further note is required on the issue of interrater reliability. Only one theme (humanitarianism) indicated a relatively low 'fair match'. While it is tempting to disregard this theme as a result, we believe it is more useful to suggest reasons for this difference in interpretation. As noted previously, Author One is a community/social psychologist and Author Two is a sociologist. There are often differences in training for these two disciplines with sociology tending to be a broader discipline than psychology. After a discussion between the two authors, it was apparent that the social psychologist was simply looking at explicit mention of humanitarianism while the sociologist included context within her analysis. As such, there was a strong implication of humanitarianism concerns in most of the Do-Gooders' responses even if it was not made explicit. These subjective differences simply draw attention to the interpretive quality of analysis rather than detracting from validity.

We first deal with the categories Do-Gooders vs. DoBadders and explicit prejudice before moving onto the six major themes.

\section{Do-Gooders or Do-Badders}

Participants were coded $1=$ Do-Gooder, $2=$ can't tell, 3 $=$ Do-Badder). An example from a Do-Gooder is:

\begin{abstract}
We are all part of 'a global village' and have responsibilities to each other across all countries and to the global environment. More privileged countries/societies like Australia need to take a greater responsibility - in this instance that means supporting the entry of people like Wasim into our country after reasonable checks. ... As a taxpayer I want my taxes to go towards building a fair, tolerant and positive multicultural Australia. Good on Phillip for courageous social commentary. Keep it up! (Participant No. 55)
\end{abstract}

An example from a Do-Badder is:

... Taxpayers have had a gutful of supporting all and sundry
while struggling to support their own families and paying
Local, State and Federal taxes. How many refugees do you
have as your neighbours? (Participant No. 1)

Interrater reliability was almost perfect $\mathrm{k}=.94(p<.001)$.

\section{Explicit prejudice}

We were also interested as to whether there was explicit prejudice espoused. We defined prejudice as a negative attitude toward an outgroup (coded $1=$ was not explicitly prejudiced, 2 = was explicitly prejudiced). An example of explicit prejudice is 
We are not a dumping ground for the world's detritus or the displaced of failed states. The rights of Australian humans to be free of the taint of those not a good fit to our culture and psyche ... is surely greater than the rights of non Australian humans. (Participant No. 43, our italics)

Interrater reliability was perfect $\mathrm{k}=1.00(p<.001)$.

\section{Emotions}

We were guided by the emotions outlined in Leach, Snider and Iyer's (2002) typology of downward comparisons; although we acknowledge that they would not have intended their typology to be used in this way. Relevant to the present study, they argued that people's focus is either on 'the self' (e.g., one may feel pride or guilt) or 'the other' (e.g., sympathy or disdain). Due to our relatively small sample size, we use these emotions as a guide only without going in depth into their complexities. Potential emotions are gloating, pride, guilt, worry, disdain, moral indignation, pity, moral outrage and sympathy. We added one additional category (miscellaneous) for emotions not explicitly covered by Leach et al.; for example, disgust. We have merged the Leach descriptions with a lay understanding of the emotions taken from the online dictionary 'dictionary.com'. When coding, precedence was given to the perceived dominant emotion; often there was more than one emotion displayed. For example, a rater may perceive a participant to be sympathetic while also being morally outraged at Wasim's situation. The rater would then make a subjective decision as to which emotion she perceived to be the most dominant. Interrater reliability for the existence of displayed emotion was almost perfect $\mathrm{k}=.94(p<.001)$.

\section{Provision of Information}

Many participants communicated what they saw as knowledge on the blog; the information varied with respect to accuracy that was included in the coding process. Some 'information' consisted of false beliefs, or myths (Pedersen, Watt, \& Hansen, 2006). Specifically, asylum seekers are believed to be 'queue jumpers' and 'cashed up' (Edmund Rice Centre, 2002; Gelber, 2003; Pedersen, Attwell, \& Heveli, 2005), to receive large amounts of government assistance (Pedersen, Attwell, \& Heveli, 2005; Refugee Council, 2002), to be illegal and not proper refugees (Pedersen et al., 2006) and to engage in 'forum shopping'; in other words, passing through countries where they could be safe in order to get to Australia (Hoffman, 2008). They were coded $1=$ did not give information at all, 2 = gave accurate information, 3 $=$ gave inaccurate information, $4=$ gave both accurate and inaccurate information, $5=$ repeated myths. At times, participants gave more than one false belief; this was entered once only. For example, Participant No. 17 talked of 'illegals' and the 'queue', and was coded once as a ' 5 '. Thus, this unit of analysis contained one or more similar or different false beliefs. Interrater reliability for the provision of information was almost perfect $\mathrm{k}=.82$ $(p<.001)$.

The remainder of the themes was gathered using an inductive approach.

\section{The Phillip Adams Effect}

Many bloggers directly addressed the author of the editorial, Phillip Adams, in their submissions (coded $1=n o$ mention of Phillip Adams, $2=$ admiring of Adams, $3=$ not admiring/aversion of Adams). Interrater reliability was almost perfect $\mathrm{k}=.91(p<.001)$.

\section{Name-Calling}

This involved whether participants called people who did not share their views unflattering names ( coded $1=$ no name-calling, $2=$ called Adams and/or Do-Gooders names, 3 = called Do-Badders/conservatives names). Interrater reliability was substantial $\mathrm{k}=.65(p<.001)$.

\section{Humanitarianism}

The final theme involved the expression of humanitarian concerns. We found that some participants displayed humanitarianism toward Wasim or asylum seekers, and others displayed what we call 'Howard Humanitarianism', which involved espousing the former conservative Prime Minister John Howard's rhetoric about the dangers to asylum seekers of attempting to gain access to Australia by boat, and the exploitation they face at the hands of people smugglers. In other words, 'Howard Humanitarianism' justifies negativity toward the phenomenon of asylum seeking through ostensible concern for asylum seekers' wellbeing (coded $1=$ did not make humanitarianism an explicit concern, 2 = indicated humanitarianism concern for Wasim or asylum seekers generally, $3=$ indicated 'Howard Humanitarianism'). Interrater reliability was fair $\mathrm{k}=.33(p<.001)$.

\section{Mentioning of Wasim}

Finally, we were interested in whether participants mentioned Wasim's case explicitly $(1=$ Did not mention Wasim, 2 = did mention Wasim). Interrater reliability for this was perfect $\mathrm{k}=1.00(p<.001)$.

\section{Results}

Given the more than satisfactory interrater reliability between the coders, the following analysis incorporates the analysis of Author 1 only. This is not to suggest that one's analysis has more validity than the other's. Indeed, the two were very similar, as shown. It is simply for ease of presentation. Before moving onto describing the results from the six major themes, we describe the results with regard to Do-Gooders vs. Do-Badders as well as explicit prejudice. There were slightly more Do-Gooders (49\%) than Do-Badders (44\%). Four participants (7\%) could not be categorised; for example, Participant No. 12 simply stated: 'couldn't agree more', and given the 
time delay in posting of responses, it is unclear which response this person was agreeing with. Data for these participants were not analysed from this point onwards. This left us with 51 participants.

Before examining the major themes, we briefly describe the results regarding explicit prejudice. We found that very few participants were explicitly racist in terms of traditional forms of racism that characterise particular groups of people as fundamentally inferior (no Do-Gooders and $17 \%$ of Do-Badders; $n=4$ ). This is not surprising given the ways in which explicit racism has come to be seen normatively as negative (Van Dijk, 1987).

We now examine the six themes in relation to the Do-Badders (see Table 1) in order of prevalence. Most common was the expression of emotion toward either Adams or Do-Gooders generally. Well over four-fifths of the Do-Badders expressed emotion (92\%); in particular, disdain, moral indignation and Australian pride. As noted, when coding we attempted to use the most dominant emotion, even when there was more than one emotion expressed (e.g., moral indignation was also often embedded within disdainful comments). The second strongest theme was an aversion, or lack of admiration, toward Adams with over three-quarters of the Do-Badders making disparaging comments about him $(78 \%)$. Third was the incidence of name-calling with over half of the sample using disparaging names for Adams or the Do-Gooders (61\%). Fourth was the provision of 'information': just over a third of participants did so $(37 \%)$. The vast majority of the information given was inaccurate or the repetition of myths identified previously in the literature. The fifth theme was

Table 1

Themes: Do-Badders

\begin{tabular}{lrc}
\hline & & $\%$ \\
\hline Emotions & $8 \%$ & $92 \%$ \\
$\quad$ No emotions indicated & $63 \%$ & \\
$\quad$ Disdain for Adams, Wasim, or Do-Gooders & $25 \%$ & \\
$\quad$ Moral indignation about asylum seekers & $4 \%$ & \\
$\quad$ Pride in Australia & & $78 \%$ \\
The Phillip Adams Effect & & $61 \%$ \\
Name-calling of Adams and Do-Gooders & & $37 \%$ \\
Provision of information & & \\
$\quad$ No information & $63 \%$ & \\
Accurate information & $0 \%$ & \\
Inaccurate information & $8 \%$ & \\
$\quad$ Both accurate and inaccurate information & $4 \%$ & \\
Myths noted in literature & $25 \%$ & \\
'Humanitarianism' & & \\
Didn't mention humanitarianism & & \\
'Wasim/asylum seeker' humanitarianism & $0 \%$ & \\
'Howard' humanitarianism & $25 \%$ & \\
Mentioning of Wasim & & \\
\hline
\end{tabular}

Table 2

Themes: Do-Gooders

\begin{tabular}{lcc}
\hline & & $\%$ \\
\hline Emotions & $67 \%$ \\
$\quad$ No emotions indicated & $33 \%$ & \\
Moral Outrage & $30 \%$ & \\
$\quad$ Sympathy & $22 \%$ & \\
$\quad$ Miscellaneous: disgust or embarrassment & $11 \%$ & \\
$\quad$ Disdain & $4 \%$ & \\
Phillip Adams Effect & & $41 \%$ \\
Name-calling of Adams and Do-Badders & & $11 \%$ \\
The provision of information & & $52 \%$ \\
$\quad$ No information & $48 \%$ & \\
Accurate information & $44 \%$ & \\
Inaccurate information & $0 \%$ & \\
Both accurate and inaccurate information & $7 \%$ & \\
$\quad$ Myths noted in literature & $0 \%$ & \\
Humanitarian concerns & & $26 \%$ \\
$\quad$ Didn't mention humanitarianism & \\
'Wasim/asylum' seeker humanitarianism & $74 \%$ & \\
'Howard' humanitarianism & $26 \%$ & \\
Mentioning of Wasim & $0 \%$ & \\
\hline
\end{tabular}

humanitarianism. While there was no mention of humanitarianism toward Wasim or asylum seekers generally, a quarter of Do-Badders (26\%) displayed 'Howard Humanitarianism'. Because the humanitarianism item only achieved fair reliability, we note that even though Author 1 found 25\% of Do-Badders espoused 'Howard Humanitarianism', Author 2 found that $38 \%$ of Do-Badders did so. Thus, the $26 \%$ should be seen as a conservative analysis. The final theme was whether they mentioned Wasim specifically: $13 \%$ did so.

We now examine the themes relating to the DoGooders (see Table 2). The most common theme was the display of emotions $(67 \%)$; in particular, moral outrage at the situation of Wasim/asylum seekers, sympathy toward Wasim/asylum seekers, miscellaneous emotions such as disgust or embarrassment at Australia's hard-line stance, and disdain. Second most common was the provision of information; half of the sample gave information (52\%) and it was overwhelmingly accurate. The third most common theme was the Phillip Adams Effect (in this case, admiration for Adams and his stance) with over a third (41\%). Fourth was specific mention of Wasim: one third of the Do-Gooders did so $(33 \%)$. Fifth was humanitarianism; approximately onequarter of participants (26\%) expressed explicit concern for Wasim/asylum seekers generally; none involved 'Howard Humanitarianism'. Because the humanitarianism item only achieved fair reliability, we note that even though Author 1 found 26\% of Do-Gooders mentioned humanitarianism, Author 2 found that $81 \%$ of DoGooders did so. Thus, the $26 \%$ should be seen as a 
conservative analysis. The final and relatively uncommon theme was the name-calling of Adams and Do-Badders; $11 \%$ of participants did so.

Finally, we were interested in whether there were differences in the prevalence of themes between the DoGooders and the Do-Badders. We note that although there were slight differences between Coder 1 and Coder 2 , the significance - or lack thereof - of the relationships remained the same. Six chi-square analyses were conducted comparing Do-Badders with Do-Gooders, which we set out below. After the chi-square analyses, we set out the percentages of participants who fell into the particular categories corresponding with Tables 1 and 2 .

With regard to the displaying of emotions, the DoBadders were significantly more likely to do so (92\%) than the Do-Gooders $(67 \%)-$ a 25 percentage point difference $-\left(\chi^{2}(1)=4.69, p=.04\right)$. With regard to the giving of accurate information, the Do-Gooders were significantly more likely to provide accurate information (44\%) than the Do-Badders $(0 \%)-$ a 44 percentage point difference $\left(\chi^{2}(1)=13.95, p<.001\right)$. With regard to the Phillip Adams Effect, the Do-Badders were significantly more likely to show this effect $(78 \%)$ than the Do-Gooders $(41 \%)$ - a 37 percentage point difference $\left(\chi^{2}(2)=37.71, p<.001\right)$. With regard to name-calling, the Do-Badders were significantly more likely to show this effect (61\%) than the Do-Gooders (11\%) - a 50 percentage point $\left(\chi^{2}(2)=22.67, p<.001\right)$. With regard to humanitarian concerns, the Do-Gooders were significantly more likely to express humanitarian concern for Wasim and/or asylum seekers (26\%) than the DoBadders $(0 \%)$ - conservatively a 26 percentage point difference. However, Do-Badders were significantly more likely (25\%) to express 'Howard Humanitarianism' than the Do-Gooders $(0 \%)$ - a 25 percentage point difference $\left(\chi^{2}(2)=12.97, p=.002\right)$. With regard to the whether or not participants mentioned Wasim specifically, although the Do-Gooders were more likely to do so $(33 \%)$ than the Do-Badders (13\%), this did not reach statistical significance $\left(\chi^{2}(1)=3.07 ; p=.11\right)$. In total, only $24 \%$ of all participants mentioned Wasim.

\section{Discussion}

Analysis of qualitative data such as blog discussions is valuable only if enough information about, and examples of, the data are provided for the reader to determine the veracity of the researchers' claims (Silverman, 2006). In this section, we discuss the main findings with respect to the Do-Gooders and Do-Badders, providing examples to illustrate the arguments. Before doing this, however, there is a feature of the data and analysis we wish to point out; that is, there was a dearth of explicitly racist responses. As previously noted, only four participants (all Do-Badders) made explicitly prejudiced comments such as:
Despite all the rhetoric trying to blame everybody else, Iraq is what it is because of the Iraqis; Afghanistan likewise; near East; Africa. ... On the other hand, Holland is what it is because of the Dutch; Denmark; Sweden; France. ... I know what kind of people I would prefer as immigrants! (Participant 50)

This may be due to the fact that comments such as the preceding one are not seen as 'politically correct'. Most people, it could be argued, would prefer not to be so straightforward with their hostility toward other, often darker-skinned, people and relying instead on modern prejudiced rhetoric (see Pedersen \& Walker, 1997; Van Dijk, 1987; Wetherell \& Potter, 1992).

We now provide illustrated examples of the major themes identified and a discussion thereof concentrating on a comparison between the Do-Badders and Do-Gooders. We describe them in the order of the largest differences between the groups; specifically, name-calling, the provision of information, the Phillip Adams Effect, humanitarian concerns, the displaying of emotion, and whether participants mentioned Wasim specifically.

\section{Name-Calling}

\section{Do-Badders}

Almost two-thirds of Do-Badders used name-calling. For example, Participant No 32 stated:

Dear Phillip it really is amazing that you know so much about the background of Wasim, and even of his father, yet the immigration department are unable to establish his identity. Which is the truth, that the immigration people know as much as you do, but are so bloody minded that they refuse to accept it, or your version of his history has come to you via your usual retinue of left wing fabricators, who will make up any story to prove themselves right? (our italics)

It has become standard practice in these debates for supporters of asylum seekers to be characterised as bleeding heart liberals and lefties, and this example, which characterises them as 'left wing fabricators', is typical of such common rhetoric.

\section{Do-Gooders}

Name-calling was the least common theme with the DoGooders. Just over one-tenth of the Do-Gooders called the Do-Badders/conservative politicians' names. However, a couple of Do-Gooders did so; for example,

I come to praise the work of Philip Adams for the intellectual and educational and informational growth of our society in Australia. Therefore, in response to all those correspondents who just like to come to a blog and have a bash at Philip, whatever he writes, in my humble opinion you lot are intellectually and educationally stunted people.

As can be seen from this quote, it is both admiring of Adams and critical of the Do-Badders on the blog.

\section{Comparison between Do-Badders and Do-Gooders}

Why were the Do-Badders significantly more likely to name-call? It may be due to the fact that there is not a 
great deal of reliable information to support their position with which to make their argument (see the section on Information below) leaving the Do-Badders with little else to say. It may also be due to a sense of entitlement. O’Brien and McGarty (2009; Study Two) made a similar observation in their study comparing those who supported mandatory detention and those who did not. It is likely that the Do-Badders felt empowered by the fact that for many years under the Howard Government they shared the dominant opinion of policymakers. This may have given them a feeling of credibility and entitlement.

\section{The Provision of Information Do-Badders}

Most Do-Badders did not provide information. And while a third did so, nobody gave accurate information alone. However, some postings contained both accurate and inaccurate information. For example, Participant No 42 stated:

Not one person has ever been detained in Australia after being accepted as a refugee (as you state) nor has one refugee ever received (sic) a bill for the costs of detention (as you state). There are two choices, you are either ignorant of what you speak, or a liar.

This latter point is an area of some confusion; while detainees were theoretically responsible for the costs of their detention at the time of the writing of this blog, most debts were not, in fact, followed up. This law was in fact revoked due to its cost, impracticality and questionable morality when it went before Senate in August 2009. It is not true, however, that people have not been detained after they were accepted as refugees. For example, after being sent to Nauru as part of what was dubbed 'the Pacific Solution', which involved sending asylum seekers to a Pacific nation while their cases were being determined in exchange for Australian aid, some who were found to be refugees were refused the right to leave (see Briskman et al., 2008).

Some information was simply inaccurate. An example comes from Participant 41 who asked of Adams: 'how do you sleep at night knowing the price of your Leftist selfrighteousness is death to women and children in sinking vessels north of Australia?' This observation presumably relates to the sinking of the SIEV X. In October 2001, 353 asylum seekers - primarily women and children died when their boat sank in the Indian Ocean (Kevin, 2004). To claim that Adams is somehow responsible for the sinking of the SIEV X is bizarre. Indeed, it has been argued (e.g., Briskman et al., 2008; Zable, 2007) that the reason there were so many women and children on the boat was because of the restrictions placed on refugee men who were on temporary protection visas, namely that family reunions were disallowed, a point taken up by current Immigration Minister Senator Chris Evans who noted that the harsh visa conditions resulted in more women and children risking their lives on leaky boats (Evans, 2008, n.p.).
The last subtheme that we discuss is that of acceptance of myths, or publicised false beliefs, such as 'seeking asylum without authorisation is illegal'. Approximately one-quarter of all the Do-Badders cited false beliefs that are well established in the literature. For example, Participant no 35 stated:

[name withheld] and the rest of you bleeding hearts - I have been travelling around for the past 12 years and NEVER has even one person said other than - you Aussies have it right, keep the doors closed to ILLEGAL immigrants. This is especially said by Brits - their country is a mess courtesy of feeding and funding illegals.

Interestingly, this was posted after Participant No. 28 provided the following accurate information: 'asylum seekers have not broken either international or Australian law by arriving without a visa seeking protection'. Clearly, the provision of accurate information does not guarantee its uptake, with Participant No 35 emphasising her insistence that asylum seekers are illegal through capitalising the word, which could also be interpreted in computerspeak as 'flaming'. The lack of explicit support for the provision of information supports the findings of Barlow, Louis and Pedersen (2008) who, in their study of prejudice against Indigenous Australians, found giving accurate information about false beliefs reduced false beliefs but not prejudice. Similarly, in another study, researchers found that simply presenting facts about older workers did not increase positive attitudes toward that group (Gringart, Helmes, \& Speelman, 2008). However, we note that the arguments made by antiracists may eventually get taken up in the discourse of those articulating more conservative views (see Fozdar, 2008) — it is just likely that they need a longer gestation period.

\section{Do-Gooders}

Unlike the Do-Badders, many Do-Gooders did impart information on the blog; in fact, just under half of the sample did so. This category links with Gale's (2004) analysis although our labelling is different. Gale writes of a human rights discourse that emphasises a search for truth. Our 'information' category also involves participants attempting to educate the Do-Badders with accurate information, such as challenging the myths of queues and illegality.

The information given by the Do-Gooders was overwhelmingly accurate. An example is a response to the comments made about rampant 'illegal immigration. Participant No. 28 stated: 'There is not rampant "illegal immigration". As we have not any common land borders, the amount of asylum seekers who arrive on our shores are very small compared to other countries like Pakistan'. The 'floodgates' rhetoric is a common myth and one that has been endorsed by Immigration Ministers in the past. For example, Phillip Ruddock famously said in an interview on the ABC's 7.30 Report that whole (Middle 
Eastern) villages were packing up to come to Australia (ABC, 1999).

However, not all information was completely accurate. Specifically, two participants gave both accurate and inaccurate information in the same blog submission. For example, Participant 22 stated:

You have missed the point. Wasim is not allowed to work or pay taxes. If he did, he would be able to subsidise you in your struggle ... My understanding is that bad decisions by the Tribubal (sic) cannot not be tested in court, but only the diligence of the process they used.

Although Wasim was not allowed to work for 4 years, he is allowed to work now. However, Participant 22 is correct that asylum seekers are bound by the decisions by the tribunal unless bad process can be claimed. The court can only deal with errors in law, not factual errors or the substance of a case (Briskman et al., 2008).

\section{Comparison Between Do-Badders and Do-Gooders}

That the Do-Gooders relied more on the giving of information appears to be an instance of the rhetorical device identified as 'the explicit use of factual detail' (see Fozdar, 2008). Those needing to counter popular views are obliged to provide more information in their arguments, rather than simple assertion. That the Do-Badders did not tend to provide such information may also be due to the sense of entitlement discussed above; the Do-Badders may have been so sure of their position that they did not see the need to provide information even if they had it.

\section{The Phillip Adams Effect \\ Do-Badders}

Well over half of the Do-Badders showed evidence of the Phillip Adams Effect involving a lack of admiration, or aversion, towards Adams. For example, 'Emotive garbage, Phil. Time to grow up'. It is difficult to know whether responses to the blog such as this are really about Wasim, or indeed asylum seekers, or about Adams himself. Adams is a controversial left-wing figure many Australians love him, many hate him.

\section{Do-Gooders}

Although the Do-Badders were significantly more likely to show evidence of the Phillip Adams Effect, this effect was still expressed by over a third of Do-Gooders. For example, 'Thanks once again for a clear and humane presentation. Aborigines and asylum seekers seem to be the divide between the powerful and the decent'. As noted previously, Adams's politics are left of centre. It is not surprising that many Do-Gooders found his politics more palatable than the Do-Badders. As an aside, a right-wing political position has been found to relate to prejudice against asylum seekers (Pedersen, Attwell, \& Heveli, 2005).

\section{Comparison between Do-Badders and Do-Gooders}

Why would the Do-Badders be more likely to show the Phillip Adams Effect? The fact that so many more Do-
Badders addressed Adams directly is most likely related to the above point about entitlement together, perhaps, with a sense of threat regarding the argument Adams is making. The responses had the flavour of retorts designed to shut down liberal arguments. What is interesting is the manner in which contributors to the blog - whether Do-Gooders or Do-Badders - engage with him personally, whether in positive or negative ways, rather than simply addressing the issues he raises.

\section{Humanitarianism \\ Do-Badders}

We noted an interesting variation of humanitarian themes that we have characterised as 'Howard Humanitarianism', used by approximately one-quarter of Do-Badders. Participant No. 21, for example, stated:

\begin{abstract}
Maybe Howard was right. Maybe the issues created for Australian society and the misery created by people smugglers taking money to put innocents on leaky boats at the mercy of pirates and wild seas is actually far worse than the downsides of the so-called Pacific solution you've spent so much energy exaggerating. And maybe rampant people smuggling and illegal immigration, which is what you seem to be advocating, actually prevents far more needy people finding a life in Australia legitimately...
\end{abstract}

This entry, which is typical of this theme, is worth closer inspection. The use of words and phrases such as 'misery', 'innocents', 'at the mercy of pirates and wild seas' indicates concern for the wellbeing of asylum seekers, as does the concern for even more worthy people who are missing out on places as a result of this trade. The writer is at pains to demonstrate that he is caring and charitable - in short, humanitarian. But it is a limited humanitarianism, which serves as a conduit for making very conservative arguments. 'Howard Humanitarianism' may involve a form of subtle prejudice or subtle racism as it is often called. As noted by Walker (2001), subtle racism often endorses egalitarianism on a surface level and people are able to maintain a self-image of being nonprejudiced (see also Van Dijk, 1987; Wetherell \& Potter, 1992) Regardless of whether Do-Badders were in fact prejudiced, and many we would imagine would strongly disagree with this assessment, the end result was often hostile and negative reporting of attitudes.

Gale (2004) also notes the link between surface humanitarianism and John Howard. As he noted, while on a surface level Howard appeals to a sort of humanitarianism, this actually serves to emphasise border protection. Part of this involved Australia being seen as facing security threats emanating from people smugglers. Interestingly, it would appear that the rhetoric about people smuggling has gained in prevalence over the years when comparing the results of the present study with those of Pedersen et al. (2006). While clearly not all of the participants in the present study have adopted these arguments, it would appear that some have. 
We make one more related point related to people smuggling. It would appear that there is a growth in people smuggling itself over the years; in particular since the mid-1990s (Koser, 2001). Koser argued that this is a consequence of western countries erecting barriers to asylum seekers. In the early 1990s, Europe in particular attempted to block the entry of asylum seekers and, as a result, asylum seeker arrivals dropped for a number of years. Numbers began to climb again; however, this time people were using smugglers because it was more difficult to move between countries, resulting in growth in smuggling syndicates.

\section{Do-Gooders}

While there was no mention of 'Howard Humanitarianism' by the Do-Gooders, just over one-quarter of participants specifically brought up humanitarianism issues. For example, Participant No. 47 stated:

When will we learn that humanitarianism benefits us all? Humans will only achieve real freedom when the respect for and nurturance of all humans becomes the code by which other freedoms are measured. When we provide a place of refuge to a human being in order to prevent human atrocity we re-humanize and dignify each of our individual lives. We lose nothing of value and gain greatly. Can we not become unified around an ethic of care?

\section{Comparison between Do-Badders and Do-Gooders}

One issue that seems to differentiate the Do-Gooders and the Do-Badders with respect to humanitarianism involves who is the appropriate target for one's humanity. Do-Badders either focused on the rights of Australians over and above those of others; or used a limited definition of humanitarian obligations, focusing on the harmful practice of asylum seeking and the need to protect people from its dangers. On the other hand, Do-Gooders argued for humanitarian approaches on two grounds - one that it is in the national character and good for Australians (see Every \& Augoustinos, 2008; Gale, 2004), the other that it is part of our responsibility to other human beings generally.

The Do-Badders were significantly more likely to state views in line with 'Howard Humanitarianism'. When examining the research of community attitudes during the Howard years, much rhetoric explicitly excluded asylum seekers from a sense of common humanity (Gale, 2004; Jupp, 2002; Pedersen et al., 2006; Saxton, 2003). Thus, our findings were not particularly surprising. Conversely, the Do-Gooders were significantly more likely to espouse humanitarian concerns either explicitly or implicitly. Again, this is not surprising given that their concern about Wasim in particular, and asylum seekers generally, relates to broader principles of human rights based on empathy, sympathy and fellow feeling. Such arguments were backed up, occasionally, with reference to Australia's obligations under international agreements.

\section{Emotions}

Most of the participants, regardless of whether they were Do-Badders or Do-Gooders, displayed emotion. However, the Do-Badders were significantly more likely to do so.

\section{Do-Badders}

Specifically, over four-fifths of Do-Badders expressed (often overlapping) emotions; in particular, disdain, moral indignation, and Australian pride. For example, Participant 52 noted:

\begin{abstract}
Say what you like Phil Australia is what it is today because of John Howards eleven years in office and the only people who seem to dislike it are you and irrational Howard haters. Even Rudd who criticized so much has almost completely followed Howards agenda. Phil perhaps you could put up the Gitmo detainees when they arrive here. In the meantime take a chill pill and get some perspective back in your column.
\end{abstract}

While there is clear disdain for Adams and the irrational Howard Haters', there also appears to be moral indignation at the heart of it. That is, the fact that the new Prime Minister from the more left-leaning party, Kevin Rudd, has followed Howard's agenda is taken as proof that this is the morally correct path.

Disdain was very common with the Do-Badders. Leach et al. (2002) found disdain can be used as a powerful tool against claims for the reduction of inequality. As they note, it can lead to total disregard for the wellbeing of the disadvantaged outgroup and in some cases (in fact, such as Wasim's situation) extreme hostility. With respect to the second most common emotion for the Do-Badders, moral indignation, Leach et al. point out that this - in the American setting at least - often relates to what is known as 'poor White racism' (p. 150) with people feeling alienated and disenfranchised by the authorities. Many bloggers appeared to frame their anti-asylum seeker arguments around resentment that refugees are benefiting from their hard-earned taxes. People who feel this way are very unlikely to become involved in efforts to decrease inequity or support asylum seekers.

Expressions of pride in Australia tended to be exclusionary and self-congratulatory within this group, supporting other research finding that high levels of Australian pride significantly correlate with prejudice against asylum seekers (Pedersen et al., 2005). Pride in their advantage as a citizen of Australia is also seen as a legitimate and fair reflection of their worth (see Leach et al. 2002). While national identity can be used to argue for inclusion of asylum seekers, as Every and Augoustinos (2008) found, for Do-Badders it had an exclusionary effect.

\section{Do-Gooders}

Like the Do-Badders, the most common theme was the expressing of emotions, although not to the same degree. 
Over two-thirds of participants displayed some form of emotion; most commonly, moral outrage and sympathy. For example, Participant No, 11 stated:

Excellent article Phillip. Surely the whole saga of the detention of boat people and their subsequent treatment in our supposedly concerned society is one of the more disgraceful episodes of the Howard years. The placing of children in detention camps was particularly disgraceful and I still don't know how Ruddock has the gall to continue to sit in the House of Reps.

Again, it was common for more than one emotion to be expressed at one time. While Participant 2 is clearly noting his moral outrage at the whole situation, he would also appear to feel sympathy for the children in detention. For this reason, we do not make too much of separating out specific emotions, instead just noted the relevance of the primary ones. Moral outrage is also a useful emotion for collective action. As Leach et al. observe, there are numerous examples of advantaged people changing the system from within (e.g., white abolitionists; male supporters of feminism) (also see Thomas, McGarty, \& Mavor, 2009).

The reporting of sympathy, as Leach et al. (2002) points out, can predispose people in an advantaged position to help those less fortunate them themselves under certain circumstances. Past research suggests that people who were supportive of a more lenient asylum seeker system were more likely to score higher on the emotion of empathy (Hartley \& Pedersen, 2007). Similarly, Reynolds (2004) found that one of the main reasons for refugee advocates to become involved in the movement was feeling empathy with the asylum seekers.

We note that no Do-Gooder (nor Do-Badder for that matter) displayed the emotion of 'guilt'. It has previously been argued that guilt is a self-blaming emotion and people tend to avoid it if they can (Iyer, Leach, \& Pedersen, 2004) and our study confirms this. However, a sense of embarrassment at being a citizen of a nation not fulfilling its international obligations was occasionally evidenced. As Participant 7 put it: 'How embarrassing it is to be an Australian travelling internationally, with all of these travesties of justice on our watch!! Where's the conscience, Mr Rudd?'

\section{Comparison between Do-Badders and Do-Gooders}

That the Do-Badders were significantly more likely to display emotions when compared with the Do-Gooders may again be due to the self-perception that participants are correct in their views and these views do not need explaining; also, they are less able to use accurate information (see above). There are also very likely to be other factors beyond the scope of our data to explain this; for example, a negative worldview, underlying racist attitudes, political conservatism (linked to prejudice against asylum seekers; Pedersen, Attwell, \& Heveli, 2005) or personality variables such as right-wing authoritarianism (see Altemeyer, 1994) that could affect the use of either hostile emotions such as disdain over emotions such as sympathy, and whether participants rely heavily on emotion.

The high levels of emotions found with both the DoGooders and the Do-Badders, particularly with respect the Do-Badders, was interesting. However, the type of emotion was very different and can be explained by the literature. In the Leach et al. typology, disdain and moral indignation (both common Do-Badder emotions) come under legitimate, other-focused emotions. The DoBadders seemed to find the fact that Wasim was left without a visa for a decade quite legitimate — it was seen as his responsibility; not Australia's. This would colour the Do-Badders' responses and require no defence of their position. In this instance it appears that the potential for empathy is circumvented by the definition of who is a legitimate focus for 'fellow-feeling'. Betts has argued that Australians reserve fellow-feeling for conationals as part of a strong sense of familial, patriotic connection to the nation (Betts, 2005). For Do-Badders, Wasim is simply not the appropriate target of Australians' empathy. However, for Do-Gooders, whose focus on humanitarianism appears to outweigh localised concerns, empathy was clearly the basis on which their arguments are made (see also Tilbury, 2007, who found pro-asylum seeker activists used familial terminology to emphasise their connection to those who deserved their empathy). Thus, empathy only appears to be triggered where the person in hardship is considered 'one of us'. This has implications for antiprejudice strategies that should focus on identity issues.

\section{Mentioning of Wasim}

Given that there was no significant difference between the Do-Badders and Do-Gooders in the mentioning of Wasim, we do not separate out by Do-Badders and DoGooders. It is interesting that so few participants wrote about Wasim, the subject of the article, regardless of whether they were Do-Badders or Do-Gooders. Specifically, over three-quarters of the whole sample did not address his situation at all, and those who did also wrote about general asylum seeker/refugee issues. This phenomenon is noteworthy as it highlights the extent to which the bloggers were articulating what has come to be a national script about asylum seeker issues. The article became a trigger for standard arguments to be made, rather than addressing the specifics of the case of this stateless individual.

Asylum seeker issues are generally value-laden. In a recent Australian community study, participants when asked why they felt the way they did about asylum seekers - overwhelmingly reported basing their attitudes, either accepting or prejudiced, on their values (Pedersen, Watt, \& Griffiths, 2008). Thus for both the Do-Gooders and the Do-Badders, it would have been easy to fall back on talking about broad value-laden principles rather than the issue at hand. 


\section{Conclusions}

Although there were similar broad themes between the two groups, as may be expected, their responses to the story of Wasim were very different. What lessons can be learnt with regard to the public discussion of asylum seekers generally?

There were a number of differences between the two groups. First, the Do-Gooders were more likely to give accurate information than the Do-Badders who were more likely to rely on media-related false beliefs. This supports past research that finds a significant relationship between false beliefs and prejudice against asylum seekers (Pedersen et al., 2005). Clearly, despite the change in Federal Government in 2007, such rhetoric is still present in public discourse. While antiracism strategists can, and should, use accurate information in attempts to change attitudes, it would appear that more than this is needed; in other words, a more holistic approach that takes into account a wider range of issues (see Pedersen, Walker, \& Wise, 2005). Second, the Do-Gooders and Do-Badders both used humanitarian arguments to strengthen their case, but very different versions of humanitarianism. This is not surprising given that past research finding that attitudes toward asylum seekers is clearly linked to values, regardless of whether attitudes are hostile or accepting. Both forms of 'humanitarianism' are value-laden. Third, Do-Badders were also more likely to name-call, and this included Phillip Adams. It is difficult for antiprejudice strategists to know how to work with this. Perhaps all that can be said is that they should be prepared for high emotions and abusive dialogue.

Finally, our emotion findings serve to confirm the quantitative findings reported previously in two important ways. First, our Do-Gooder participants did not report guilt, which supports the findings of previous Australian studies such as Hartley and Pedersen (2007). In that study, although guilt and empathy were correlated, mean levels of empathy were far greater than mean levels of guilt, which were low. Thus, antiprejudice strategists may be advised not to concentrate on guilt, which is an unpleasant emotion that people attempt to avoid (see Leach et al., 2002), but concentrate on less aversive emotions like empathy. Also, our participants often had multiple emotions reported at the same time. As noted previously, although one can experimentally manipulate emotions in the laboratory, in the real world, they are often found together. In fact, previous quantitative research finds this. In a study by Leach, Iyer and Pedersen (2006), the correlation between anger and guilt was substantial (see similar results from Hartley \& Pedersen above). Finally, given Cohen's (2007) point made previously about research benefiting from many methods, this triangulation of method regarding emotion - qualitative and quantitative - adds to the literature in an interesting way.
To return to the subject at hand - Wasim - Phillip Adams concluded in his article: So Kev, Rob and Chris, tis the season for three wise men to hop on their bikes - or their camels - and do the right thing for the Wasims. Perhaps he could be given nationality by Australia Day? I'm happy to provide his details...

('Kev' refers to Kevin Rudd, Australia's Prime Minster, 'Rob' refers to Robert McClelland, Australia's Attorney General and 'Chris' refers to Chris Evans, Australian's Immigration Minister). This did not occur, nor has it occurred at the time of writing this article.

\section{References}

ABC. (1999). Australia a new target for displaced Iraqis. The 7.30 Report [Television program]. Retrieved January 10, 2008, from http://www.abc.net.au/7.30/stories/s66377.htm

Adams, P. (2008, December 20-21). Refugees without refuge. In The Weekend Australian Magazine, p. 30.

Altemeyer, B. (1994). Reducing prejudice in right-wing authoritarians. In M.P. Zanna \& J.M. Olson (Eds.), The psychology of prejudice: The Ontario Symposium (Vol. 7, pp. 131-148). Hillsdale, NJ: Erlbaum.

Barlow, F.K., Louis, W.R., \& Pedersen, A. (2008). [The impact of challenging false beliefs vs inciting collective guilt, on a range of intergroup attitudes]. Unpublished dataset.

Betts, K. (2005). Cosmopolitans and patriots: Australia's cultural divide and attitudes to immigration. People and Place, $13,29-40$.

Billig, M. (1987). Arguing and thinking: A rhetorical approach to social psychology. Cambridge: Cambridge University Press.

Braun, V., \& Clarke, V. (2006). Using thematic analysis in psychology. Qualitative Research in Psychology, 3, 77-101.

Briskman, L., Latham, S., \& Goddard, C. (2008). Human rights overboard: Seeking asylum in Australia. Melbourne, Australia: Scribe.

Cohen, D. (2007). Methods in cultural psychology. In S. Kitayama \& D. Cohen (Eds.), Handbook of cultural psychology (pp. 196-236). New York: The Guilford Press.

Couldrey, M., \& Herson, M. (Eds.). (2009). Statelessness. Forced Migration Review. Retrieved April 7, 2009, from http://www. fmreview.org/aboutus.htm

Crock, M.E., \& Saul, B. (2002). Future seekers: Refugees and the law in Australia. Annandale, Australia: Federation Press.

Edmund Rice Centre for Justice and Community Education. (2002). Debunking the myths about asylum seekers. In J. Healey (Ed.), Australia's immigration debate: Issues in Society (pp. 29-31). Rozelle, Australia: The Spinney Press.

Evans, C. (2008). Budget 2008-09: Rudd Government scraps Temporary Protection visas. [Media Release]. Retrieved February 5, 2009, from http://www.minister.immi.gov.au/ media/media-releases/2008/ce05-buget-08.htm

Every, D., \& Augoustinos, M. (2008). Constructions of Australia in pro- and anti-asylum seeker discourse, Nations and Nationalism, 14, 562-580.

Fozdar, F. (2008). Duelling discourses, shared weapons: Rhetorical techniques used to challenge racist arguments. Discourse and Society, 19, 529-547. 
Gale, P. (2004). The refugee crisis and fear: Populist politics and media discourse. Journal of Sociology, 40, 321-340.

Gelber, K. (2003). A fair queue? Australian public discourse on refugees and immigration. Journal of Australian Studies, 1, 23-30.

Glaser, B., \& Strauss, A. (1980). The discovery of grounded theory: Strategies for qualitative research (11th ed.). New York: Aldine Transaction.

Gringart, E., Helmes, E., \& Speelman, C. (2008). Harnessing cognitive dissonance to promote positive attitudes toward older workers in Australia. Journal of Applied Social Psychology, 38, 751-778.

Hartley, L., \& Pedersen, A. (2007). Asylum seekers: How attributions and emotion affect Australians' views on mandatory detention of 'the other'. Australian Journal of Psychology, 59, 119-131.

Hoffman, S. (2008). Exploration into the interrelationship between the hopes and expectations of Iraqi asylum seekers who arrived in Australia as unauthorised arrivals between 1999 and 2001, and their experiences en route. Unpublished manuscript, Murdoch University, Australia.

Iyer, A., Leach, C.W., \& Pedersen, A. (2004). Racial wrongs and restitutions: The role of guilt and other group-based emotions. In N.R. Branscombe \& B. Doosje (Eds.), Collective guilt: International Perspectives (pp. 262-283). Melbourne, Australia: Cambridge University Press.

Jupp, J. (2002). From White Australia to Woomera: The story of Australian immigration. Cambridge, Cambridge University Press.

Kevin, T. (2004). A certain maritime incident: The sinking of the SIEV X. Melbourne, Australia: Scribe Publications.

Koser, K. (2001). New approaches to asylum. International Migration, 39, 101.

Landis, J.R., \& Koch, G.G. (1977). The measurement of observer agreement for categorical data. Biometrics, 33, 159-174.

Leach, C.W., Iyer, A., \& Pedersen, A. (2006). Anger and guilt about in-group advantage explain the willingness for political action. Personality and Social Psychology Bulletin, 32, 1232-1245.

Leach, C.W., Snider, N., \& Iyer, A. (2002). 'Poisoning the consciences of the fortunate': The experience of relative advantage and support for social equality. In I. Walker \& H.J. Smith (Eds.), Relative deprivation: Specification, development, and integration (pp. 136-163). Cambridge: Cambridge University Press.

Liamputtong, P., \& Ezzy, D. (2005). Qualitative research methods. South Melbourne, Australia: Oxford University Press.

Manne, R., \& Corlett, D. (2004). Sending them home: Refugees and the new politics of indifference. Quarterly Essay, 13, $1-96$.

Mares, P. (2002). Borderline. Sydney :University of NSW Press.

OBrien, L.V. \& McGarty, C. (2009). Political disagreement in intergroup terms: Contextual variation and the influence of power. British Journal of Social Psychology, 48, 77-98.
Pedersen, A., Attwell, J., \& Heveli, D. (2005). Prediction of negative attitudes toward Australian asylum seekers: False beliefs, nationalism and self-esteem. Australian Journal of Psychology, 57, 148-160.

Pedersen, A., Kenny, M.A., Briskman, L., \& Hoffman, S. (2008). Working with Wasim: A convergence of community. The Australian Community Psychologist, 20, 57-72.

Pedersen, A., Walker, I., \& Wise, M. (2005). 'Talk does not cook rice': Beyond anti-racism rhetoric to strategies for social action. The Australian Psychologist, 40, 20-30.

Pedersen, A., \& Walker, I. (1997). Prejudice against Australian Aborigines: Old-fashioned and modern forms. The European Journal of Social Psychology, 27, 561-587.

Pedersen, A., Watt, S., \& Griffiths, B. (2008). Prejudice against Australian asylum seekers and their function: Suggestions for anti-prejudice strategies. In H. Babacan \& N. Gopalkrishnan (Eds), The complexities of racism: Proceedings of the Second International Conference on "Racisms in the New World Order". Queensland: University of the Sunshine Coast.

Pedersen, A., Watt, S., \& Hansen, S. (2006). The role of false beliefs in the community's and the federal government's attitudes toward Australian asylum seekers. Australian Journal of Social Issues, 4, 105-124.

Pickering, S. (2001) Common sense and original deviancy: News discourses and asylum seekers in Australia. Journal of Refugee Studies, 14, 169-186.

Refugee Council of Australia (2002). Facts and stats. Retrieved March 28, 2002, from http://www.refugeecouncil.org.au/ html/facts_and_stats/facts.html

Reynolds, M. (2004). (Australians welcome refugees: The untold story). Unpublished document.

Saxton, A. (2003). 'I certainly don't want people like that here': The discursive construction of asylum seekers. Media International Australia incorporating Culture and Policy, 109, 109-120.

Silverman, D. (2006). Interpreting qualitative data: Methods for analyzing talk, text and interaction (3rd ed.). London: Sage.

Tilbury, F (2007). 'We are family': the use of family tropes in refugee/advocate talk'. Journal of Social Identities, 13, 627-649.

Thomas, E.F., McGarty, C., \& Mavor, K.I. (2009). Transforming 'apathy into movement': The role of prosocial emotions in motivating action for social change. Personality and Social Psychology Review, 13, 310-333.

Van Dijk, T. (1987). Communicating racism: Ethnic prejudice in thought and talk. CA: Sage.

Walker, I. (2001). Changes in prejudice against Aboriginal Australians. In M. Augoustinos \& K. J. Reynolds (Eds.), Understanding prejudice, racism and social conflict (pp. 24-42). London: Sage.

Wetherell, M., \& Potter, J. (1992). Mapping the language of racism: Discourse and the legitimation of exploitation. UK: Harvester-Wheatsheaf.

Zable, A. (2007). Perilous journeys. In D. Lusher \& N. Haslam (Eds), Yearning to breathe free: Seeking asylum in Australia (pp. 64-74). Sydney, Australia: Federation Press. 